\title{
Job Security and Performance: Case Study of the Albanian Public Administration
}

\author{
Gentiana Kraja PhD. \\ Universitety "Aleksandër Moisiu”, Durrës, Albania \\ gentianakraja@yahoo.com
}

\section{Doi:10.5901/ajis.2015.v4n2p19}

\section{Abstract}

Job security in a simple language is defined as the knowledge that your job is permanent as long as you want to be. Defined in this way is understandable that job security involves the emotional part of the individual, and in the other hand is a real challenge for the organization for the consequences it may have. For that reason job security is treated as an important practice of human resources management and not like an isolated episode. Public organizations operate under several pressures, as politics, legal framework, group of interest. The main purpose of this paper is to present the main theoretical approaches related to job security and how it is perceived in influencing performance. Further, in a more practical level, other purpose of this paper is to analyze the relationship of job security with performance seen in two levels; individual and organizational. To realize the goals of this paper are following two main ways. Initially he conducted a theoretical picture of attitudes to assess performance and its position in view of the performance of public administrator. Later in order to answer to key questions of research is designed and distributed a questionnaire on the Albanian public administration whose data are processed further. At the end of this work based on literature review and practical results are reflected some recommendations and conclusions.

Keywords: job security, public administrator performance, organizational performance.

\section{Introduction}

Because of all pressures as politics, competition, globalization, deregulations and rising costs, companies have been forced to restructure their organizations, in terms of business, finances, processes and structures. Because of this dynamism and pressure some episodes as merging, downsizing and reorganization have turned out to be more and more widespread in the last two decades in USA and Europe. (Burke \& Cooper, 2000). These transformations have changed the nature of work and caused feelings of uncertainty, stress and anxiety for many workers about the existence and the features of their job (De Witte \& Goslinga, 2004). In the last twenty years, research has generated wide empirical evidence about the negative impact of a job lost on a number of aspects related both to individuals' well being and to organizational functioning (Sverke, Hellgren \& Näswall, 2002). Job security is a topic where the balance of benefits and costs are still relatively unknown. For example, employees with high job security may invest more in their companies out of loyalty or because they view their jobs as long term commitments. On the other hand, workers may take advantage of their job security and do as little work as possible. Job security can also be costly to the firm since dismissal of employees requires more time, effort, and compensation.(Leung. W., 2009)

Since the beginning of this paper we defined job security and relation to job performance, but what we are afraid of is job insecurity, but since these two concepts are different sides of the same coin, the absence of one is the other. In fact what causes the damage is job insecurity this way some author have related job insecurity with some of the individual parameters. So high conviction of job insecurity were associated to lower job satisfaction and organizational commitment (Chirumbolo \& Hellgren, 2003). Other relation explored was with turnover or, intention to quit the organization (Davy, Kinicki \& Scheck, 1997), reduced organizational trust (Ashford et al., 1989), and also related to a lower job performance (Probst, 2002b).

\section{Methodology}

\subsection{Main questions of the research}

How is job security influencing organizational performance?

How is influenced the performance of public administrator from job security?

Which is the dynamism of this mechanism under the influence of various individual and organizational factors?

In an effort to realize the main purpose of this study work is oriented by two main directions. Originally it realized a 
theoretical framework to reflect different approaches regarding job security, performance of the public administrator as the mechanism for the performance of public organizations. Job security is represented in this paper as the procedure of a constructed action plan that organization uses to improve inputs and outputs of public administrator. While public administrator performance is represented by the individual inputs and outputs: first connect with skills and expertise, motivation and opportunities for participation, while the latter attitudes towards work as satisfaction, involvement and commitment to and results of work.

In the second part the study is directed towards practical research, data analysis originally was done between descriptive statistical analysis and testing hypotheses through the econometric model of multiple and simple linear regression by the method of least squares ( OLS). Database was provided by primary sources through primary data collection therefore directly from the investigator. This process took place between creation and distribution of a questionnaire. For the design of the questionnaire initially we relied on the theoretical framework, but also in the interviews conducted for this purpose with representatives of the departments of human resources management of some public organizations. The questionnaire was designed with closed questions. The questions were in the form of statements, where respondents are required to hold a position from 1 - Strongly disagree 5 - I totally agree. 500 questionnaires were distributed and the data were processed on the statistical program STATA version 11.

\section{Literature Review}

Job security can be defined as protection against job loss. This is and will probably be a big concern for the individual. One of the reasons that individuals join the organization is precisely this moment. There are some authors who think enough job security associated with work. If employees should be cut first to leave they are those with less experience work (Koli, Z., Llaci, Sh., (2005). Job security often implies security of a job within a particular organization and job security related to an individual's career (R. Wayne Mondy., Noe, M. R., (2005).. So in short, job security has to do with how much a person feels safe and protected in the fact of losing his job involuntarily. However, during the exploration about different attitudes to job security has also revealed that another concept that includes job security and it is security of employment, it has to do with rights and mechanisms to reinforce these right about the fact of staying in work of an individual more than to remain in the job in a particular organization, but this is a very broad concept and involves many other factors that lie outside the main purpose of the study as for example employment policies of a given country, the macro and micro parameters etc. job security remains a hallmark of employment and related issues in the public sector (Human Capital Institute. 2009). This is a very big advantage because it allows true and professional staff committed to the job and devotes full attention to work than to worry about their job security. On the other hand is a security measure for some not very professional because employees do not bother to improve their performance as it does not jeopardize their work. So job security in public organizations seems to be quite safe in terms of theoretical approaches about. On the other hand Armstrong (2009) states that nowadays an eternal career no longer exists in the case of public administrator, he does not enjoy it most certainly has had in building an everlasting career in the public sector. As quoted by Armstrong (2009), author Hiltrop work suggests that security is part of a new psychological contract between employer and employee created. However, this author believes that this contract about job security should be defined as follows: there is no job security. The employee will be employed until he is able to add value to the organization and is personally responsible for finding new ways to add value, to return the employee has the right to seek work interesting and important, is free and resources to perform it well, it gets a salary that reflects his contribution and takes experience and training necessary to be employable in this organization or elsewhere (Armstrong, M., 2009).

\subsection{Public Administrator Performance}

The effect of job security will be seen initially in relation with public administrator performance and then with organizational performance. The public administrator performance is represented as the product of their individual characteristics or its inputs and outputs, its results. Characteristics with which the individual comes to the organization and serve as "raw material" for the application of managerial practices of human resource management are: skills, motivation and opportunities. If managers want to impact positively on individual performance, they must affect on these three components (Boxall, P., Purcell. J., 2003 \& 2011).

Let's briefly explain each of them.

Skills indicate what the individual is able to do. To perform successfully on all tasks involving a particular work, the individual must have some skill and dexterity. Skill seen as the product of physiological and biological factors and the 
learning process and it is difficult to change. Really that authors are of the opinion that the skills are determined by genetic factors, but there are many others who claim that these "limits" break up to some extent by learning (Kasimati, M. 2010).. Motivation reflects the decisions taken by the individual for it to do, the intensity with which the make and how long will do (Kasimati, M. 2010).

Opportunities for participation refer to the fact that many organizations or individuals create opportunities and promote the expression of the individual's skills and work. Often it is giving opportunity seen as part of the perception of the role and the psychological contract between employer and employee created. Psychological contract, particularly in the public sector, is quite concerning the reliability not only to the organization and the public administrator, but in this case and the state government, with the expectations and opportunities given to the public administrator and public self (Willems, I., Janvier, R., Henderickx, E., 2004). On the other hand the performance of public administrator is the performance of human resources results. Based on theoretical positions as Becker ('96, 1997) which identifies the output productivity, Guest (1997), which identifies the involvement and civic behavior, work or output results, Purcell ('99, '02, 2003) order job satisfaction, output, and Nishii Wright (2006) self motivation or motivate behavior as part of the output, in the summary of these theoretical approaches public administrator results obtained in this study represented by: job satisfaction, commitment and involvement, motivation / behavior motivated, civic behavior in the organization/organization discrete behavior.

\section{The Study Design and Data Analysis}

For the realization of this study was compiled and distributed a questionnaire with 52 questions, were distributed 600 questionnaires but only 500 were available for further processing of data. The questionnaire was distributed only in public organizations while the focus of this study public administrator. The data are based on personal perceptions that public administrators interviewed about job security, the way it is perceived its self and then in function of improving the performance of public administrator or public organization, job performance of public administrator and organizational performance. To select the source of the first public institutions was approved budget of the Ministry of Finance for 2015, later addressed the website of each institution to verify the accuracy of the list under its institutions, and on this basis was created a database on the form of a genuine network of connections that served as a guide for data collection. Then the selection of respondents in each institution was fortuitous by distributors then collected from the contact person. At the end of data collection resulted in a relatively successful process was taken seriously either by the persons who were either distribution by respondents.

Key elements of the model, then the variables are: job security, which is the independent variable of the model. Public administrator's performance, which is seen as the product of its input and output. Public administrator's performance depending on the connection being tested behaves times as dependent variable and time as the independent variable. Public organization's performance is increasingly dependent variable. At the beginning of this questionnaire the interviewee is asked about some of his biographical characteristics such as age gender, education, etc., as well as the characteristics of the organization as the central public administration or local, big or small, etc..

\section{Analysis of Results}

\subsection{Sample description}

Referring whether respondents belong central public administration, local or other category describes sample $48.2 \%$ are central public administration, $34.8 \%$ belong to the local public administration while $17.0 \%$ belong to other categories. Regarding the characteristics of the sample size according to data processing by gender shows that $38.6 \%$ are male and 61.4 are female, while in terms of educational attainment for the sample described by $77.2 \%$ with university degrees, $21.6 \%$ have completed studies of second cycle - Master, while 1.2\% have scientific degree 'Doctor'. Respondents were also asked about their position in the structure or hierarchy of the organization, finding that $77.8 \%$ of them are in the current position of specialist, $16.8 \%$ of them are in charge of the sector position while $5.4 \%$ are in the position of director.

\subsection{Descriptive Statistics}

In the table below the descriptive statistics about the means of the variables, independent - job security, dependent variable - public organization performance, and public administrator performance, in function of individual or organizational characteristics. 


\begin{tabular}{|l|c|c|c|c|}
\hline \multirow{2}{*}{ Ind./Org. Characteristic } & \multirow{2}{*}{ Job security (Independent Variable) } & \multicolumn{2}{|l|}{ Public Administrator Performance } & \multirow{2}{*}{ Organizational performance (Depend. Variable) } \\
\cline { 3 - 5 } & & Input & Output & \\
\hline Central Administration & 3.2 & 3.9 & 3.6 & 3.6 \\
\hline Local Administration & 3.8 & 4.1 & 3.8 & 3.9 \\
\hline Gender - male & 3.4 & 4 & 3.6 & 3.7 \\
\hline Gender - female & 3.5 & 1 & 3.7 & 3.8 \\
\hline Age 21-40 & 3.7 & 3.9 & 3.6 & 3.6 \\
\hline Age 40-65 & 3.5 & 4.1 & 3.7 & 3.9 \\
\hline High education & 3.5 & 4 & 3.7 & 3.2 \\
\hline Master & 3.3 & 4 & 3.7 & 3.8 \\
\hline Doctorate & 4.1 & 4.4 & 4.1 & 4.1 \\
\hline
\end{tabular}

As described before the respondents were asked to take attitude (expressed in 1 don't agree to 5 totally agree) to the declarative questions, in synthesis of which we can draft some descriptive statistics that are reflected in the table below:

As we can see from the table before, job security has its best value when respondents are from local government or when they have PhD degree. When we discuss the public administrator performance its inputs have the best value is when the respondents are in the interval of age form $40-65$, and when they have PhD degree. Outputs have a constant lower result of the mean then other three categories, while inputs have the highest results the other three categories. From the individual or organizational characteristic point of view respondents from local government and that have "Doctorate" degree have constantly the best results from the four categories.

\subsection{Linear regression analysis regarding the hypothesis}

To begin to answer to the questions asked before, the first step is to test the relation of job security with the inputs and outputs of public administrator, is it really perceived by individual that job security at their organization has an impact on their skills, abilities, productivity, and does this has a influence on the public administrator performance. For these reasons the first hypothesis is Ho: job security does not have any impact on public administrator performance. So after regressing job security on inputs and outputs, so public administrator performance, we have the following table:

Table 1. Job security regression performance public administrator

\begin{tabular}{|c|c|}
\hline Public administrator performance & OLS \\
\hline Job security & $\begin{array}{c}.3004144^{* * \star} \\
(.0249841)\end{array}$ \\
\hline Gender male & $\begin{array}{l}-.0644476 \\
(.0419696)\end{array}$ \\
\hline Status marries & $\begin{array}{l}-.0596424 \\
(.0534239)\end{array}$ \\
\hline Medium org. & $\begin{array}{c}.0861573 \\
(.0659348)\end{array}$ \\
\hline Big org. & $\begin{array}{c}.0771911 \\
(.0689643)\end{array}$ \\
\hline Age & $\begin{array}{c}.003519 \\
(.0033623)\end{array}$ \\
\hline Years in public administration & $\begin{array}{c}-.0003746 \\
(.0033688)\end{array}$ \\
\hline Central PA & $\begin{array}{c}-.1221761 \\
(.0578636)\end{array}$ \\
\hline Local PA & $\begin{array}{c}-.0603976 \\
(.0593061)\end{array}$ \\
\hline No. of persons in charge & $\begin{array}{c}.0703806 * * * \\
(.0177911)\end{array}$ \\
\hline $\mathbf{R}^{2}$ & 0.3338 \\
\hline No. of observations & 500 \\
\hline$\beta_{0}$ & $\begin{array}{c}2.597153 * * * \\
(.1351202)\end{array}$ \\
\hline $\begin{array}{l}\text { Note: * } 10 \% \text { statistical significance } \\
\star \star 5 \% \text { statistical significance } \\
\star \star \star 1 \% \text { statistical significance }\end{array}$ & \\
\hline
\end{tabular}


Job security presents a statistically significant coefficient as $p$ - value $<0.01$, the value of this coefficient is $\beta 1=$ 0.3004144 , we note that is a relatively high value. Gender male, married status, the central public administration, and represent negative values of their coefficients thus have a negative relationship with individual characteristics and public administrator performance at work.

In this case the null hypothesis and the alternative hypothesis are as follows:

Ho: job security does not affect the performance of public administrator.

Ha: 8 job security has an impact on the performance of public administrator.

The model is statistically significant when $p$-value $<0,01$. The coefficient of determination $R^{2}=0.3338$ which means that $33.38 \%$ of dependent variables so public administrator's performance is explained by the independent variable so job security. To achieve this number of observations was 500 , the level of importance of this model is significant, in this way we can say that the null hypothesis falls and the alternative hypothesis is confirmed, then job description has a significant impact on the performance of public administrator and individual characteristics.

Equation 1 in this case would have the form:

'Performance of the public administrator' $=2.597153+0.3004144$ 'job security'

However one of the main questions of this study was associated security and its impact on organizational performance, so job security now is regressed with public organization performance, but through the effect of public administrator performance. After the regression is obtained the following table.

Table 1. Regression explaining organizational performance from job security and performance of the public administrator

\begin{tabular}{|c|c|}
\hline Public organization performance & OLS \\
\hline Job security & $\begin{array}{c}0.1280839 \star \star \star \\
(0.0194517)\end{array}$ \\
\hline Inputs (AMO) & $\begin{array}{c}0.3123735^{\star \star \star} \\
(0.0337281)\end{array}$ \\
\hline Outputs & $\begin{array}{c}0.5492015^{\star \star \star} \\
(0.0401835)\end{array}$ \\
\hline Gender (male) & $\begin{array}{l}-0.0034489 \\
(0.0288439)\end{array}$ \\
\hline Status (married) & $\begin{array}{l}0.0040093 \\
(0.036494)\end{array}$ \\
\hline Medium org. & $\begin{array}{c}0.1895169^{* * *} \\
(0.0453736)\end{array}$ \\
\hline Big org. & $\begin{array}{l}0.1285041^{\star \star \star} \\
(0.04713118)\end{array}$ \\
\hline Age & $\begin{array}{c}0.0013845 \\
(0.0022967)\end{array}$ \\
\hline Years in PA & $\begin{array}{c}-0.0049444^{\star *} \\
(0.0022985)\end{array}$ \\
\hline Central PA & $\begin{array}{l}-0.0059484 \\
(0.039656)\end{array}$ \\
\hline Local PA & $\begin{array}{c}-0.0022688 \\
(0.0405083)\end{array}$ \\
\hline No. of persons in charge & $\begin{array}{c}0.0001156 \\
(0.0123318)\end{array}$ \\
\hline $\mathbf{F}$ & 132.54 \\
\hline $\mathbf{R}^{2}$ & 0.7656 \\
\hline No. of observations & 500 \\
\hline $\begin{array}{l}\beta_{0} \\
\text { Note: * } 10 \% \text { statistical significance } \\
\star \star 5 \% \text { statistical significance } \\
\star \star \star 1 \% \text { statistical significance }\end{array}$ & -0.1255193 \\
\hline
\end{tabular}

Job security in this model represents the assurance that individual about having a job for as long as one wants it. This variable has a statistically significant coefficient as $p=$ value $<0: 01$, the value of this coefficient is $\beta 1=0.1280839$. As can be seen in the second regression coefficient value of job security falls, so the effect of job security feature when viewed in the public organization's performance falls. Gender male, married status, central and local public administration, public 
administration years, the number of dependents present negative values of their coefficients thus have a negative relationship with the performance of public organizations. It is worth analyzing the external features years in public administration and the number of dependents. Years in the public administration in this equation has a negative relationship with job security and also organizational performance, so individuals with more experience in public administration tend to have a less positive perception of job security and the impact that it has on the performance of public organizations. While the number of dependents that until now in most organizational performance regressions resulted negative in this case results in a positive sign which means that if there is a positive relationship with job security if organizational performance, however it has a $p$ - value $>0.1$ share and is statistically insignificant.

In this regression, hypothesis null and alternative hypotheses are as follows:

Ho: job security does not affect the performance of public organizations.

Ha: job security has an impact on the performance of public organizations.

The model is statistically significant when p-value $<0,01$. The coefficient of determination $\mathrm{R} 2=0.7656$ which means that $76.56 \%$ of dependent variables therefore organizational performance is explained by the independent variable so job security, individual inputs and outputs. To achieve this number of observations was 500 , the level of importance of this model is significant, in this way we can say that the null hypothesis falls and the alternative hypothesis is confirmed, then job security has a significant impact on the performance of public organizations.

Equation 2 in this case would have the form:

'Performance of the public organization' $=0.1280839-0.1255193+$ 'job security' +0.3123735 'inputs' +0.5492015 'output'

\section{Conclusions}

Job security is in practice that in this study has the sense of security that no individual having and keeping a certain position, if it so wishes. Job security is a practice which results important as explaining the individual outputs as well as the performance of public organizations. This practice results irrelevant to the explanation of the individual inputs. Which means that the self-expression of the individual within the organization and making available its skills and energy security-related not having it for work and this is a positive for our public administration, however there is room for further investigate the reasons for this fact. Family and personal commitments of individuals and affect his job security in important and positive way, the same thing happens with individual experience in public administration. Which means that the experience in public administration, makes the individual feel more sure of his place of work. We can not give an indication about the influence of politics on job security as attitudes towards this phenomenon are neutral. This neutrality can be interpreted in different ways, can be interpreted as a kind of neutrality or indifference with regard to political affiliations and the impact that they have on job security in the public administration, this interpretation would be very positive. On the other hand neutrality can be interpreted as reluctance to give an honest answer and it would be a scenario not likeable about the impact of the political affiliations of job security. However there is room to think that the public administration does not perceive significant political affiliation for the job after the interval in which neutrality is oriented answers revolve more contrary to the presence of political affiliation rather than on acceptance of this presence.

\section{References}

Armstrong, M., (2009). Human Resource Management in practice. by Saxon Graphics Ltd, Derby.

Human Capital Institute. (2009). The impact of Strategic Human Resource Management on Organizational Success: the public sector and multiple goals. The global association for strategic talent management.

Koli, Z., Llaci, Sh., (2005). Menaxhimi i Burimeve Njerëzore (botmi Il-të), Albpaper, Tiranë

R. Wayne Mondy., Noe, M. R., (2005). Human resource management. Pearson Education Ltd.

Ashford, S. J., Lee, C. \& Bobko, P. (1989). Content, cause, and consequences of job insecurity: A theory-based measure and substantive test. Academy of Management Journal, 32, 803- 829.

Becker, B. \& Gerhart, B. (1996) The impact of Human Resource Managemenet on Organizational Performance: Progress and prospects. Special Research Forum on Human Resource Management and Organizational Performance. Academy of Management Journal, 39 (4), 770-801.

Becker, B.E., Huselid, MA., Pickus. PS., \& Sprats, M . (1997) . HR as a source of shareholder value: Research and recommendations. Human Resource Management, 36, 39-47.

Burke, R. J. \& Cooper, C. L. (Eds.). (2000). The organization in crisis; Downsizing, restructuring, and privatization. Oxford: Blackwell.

Chirumbalo. A., (2005) The influence of Job insecurity and job performanceand absenteeism: the moderating effect of work attitudes. Journal of Industrial Psychology 31 (4), 65-71 
Chirumbolo, A. \& Hellgren, J. (2003). Individual and Organizational consequences of Job Insecurity: a European study. Economic and Industrial Democracy, 24, 215-238.

Davy, J. A., Kinicki, A. J. \& Scheck, C. L. (1997). A test of job security's direct and mediated effects on withdrawal cognitions. Journal of Organizational Behavior, 18, 323-349.

Guest, D. E., (1997). Human resource management and performance: a review and research agenda. The International Journal of Human Resource Management, 8(3), 263-276.

Leung. W., (2009). Job security and Productivity: Evidence from Academics Department Economics. University of California, Berkley.

Probst, T. M. (2002b). Layoffs and tradeoffs: Production, quality and safety demands under the threat of job loss. Journal of Occupational Health Psychology, 7, 211-220.

Purcell, J., (1999). Best practice and best fit: chimera or cul - de - sac? Human resource management journal. Vol. 9. No. 3. Pg. 26 41.

Purcell. J. (2002). Sustaining the HR and performance link in difficult times. Employment research project at the university of Bath. CIPD.

Sverke, M., Hellgren J. \& Näswall, K. (2002). No security: a meta-analysis and review of job insecurity and its consequences. Journal of Occupational Health Psychology, 7, 242-264.

Wright, P. M., \& Nishii, L. H. (2006). Strategic HRM and organizational behaviuor: integrating multiple levels of analysis. CARHS Working Paper Series, 05. Available at: <http://ilr.corneli.edu/CAHRS>. 
